\title{
Suppressed Angiogenesis in Kininogen-Deficiencies
}

\author{
Izumi Hayashi, Hideki Amano, Satoko Yoshida, Kazuhisa Kamata, Mariko Kamata, \\ Madoka Inukai, Tomoe Fujita, Yuji Kumagai, Sen-ichi Furudate, and \\ Masataka Majima
}

\author{
Department of Pharmacology (IH, HA, KK, MK, MI, TF, YK, MM), Department of Thoracic Surgery (SY), and \\ Department of Animal Sciences (S-iF), Kitasato University School of Medicine; and Department of Molecular \\ Pharmacology (IH, KK, YK, MM), Kitasato University Graduate School of Medical Sciences, Kitasato, Sagamihara, \\ Kanagawa, Japan
}

\begin{abstract}
SUMMARY: We investigated whether the kinin-generating system enhanced angiogenesis in chronic and proliferative granuloma and in tumor-surrounding stroma. In rat sponge implants, angiogenesis was gradually developed in normal Brown Norway Kitasato rats $(\mathrm{BN}-\mathrm{Ki})$. The development of angiogenesis was significantly suppressed in kininogen-deficient Brown Norway Katholiek rats (BN-Ka). The angiogenesis enhanced by basic fibroblast growth factor was also significantly less marked in BN-Ka than in BN-Ki. Naturally occurring angiogenesis was significantly suppressed by $B_{1}$ or $B_{2}$ antagonist. mRNA of vascular endothelial growth factor was more highly expressed in the granulation tissues in BN-Ki than in BN-Ka. Daily topical injections of aprotinin, but not of soy bean trypsin inhibitor, suppressed angiogenesis. Daily topical injections of low-molecular weight kininogen enhanced angiogenesis in BN-Ka. Topical injections of serum from BN-Ki, but not from BN-Ka, also facilitated angiogenesis in BN-Ka. FR190997, a nonpeptide mimic of bradykinin, promoted angiogenesis markedly, with concomitant increases in vascular endothelial growth factor mRNA. Angiogenesis in the granulation tissues around the implanted Millipore chambers containing Walker-256 cells was markedly more suppressed in BN-Ka than in BN-Ki. Our results suggest that endogenous kinin generated from the tissue kallikrein-kinin system enhances angiogenesis in chronic and proliferative granuloma and in the stroma surrounding a tumor. Thus, the agents for the kinin-generating system and/or kinin receptor signaling may become useful tools for controlling angiogenesis. (Lab Invest 2002, 82:871-880).
\end{abstract}

$A$ ngiogenesis contributes to various physiologic processes, including embryonic development, the female reproductive cycle, and wound repair, as well as to pathologic conditions, such as tumor growth, diabetic retinopathy, and rheumatoid arthritis (Folkman, 1971; Michaelson, 1948; Peacock et al, 1992; Wise, 1956). Angiogenesis itself is a complex multistep process that may be regulated by a variety of bioactive substances, including growth factors, inflammatory cytokines, and proinflammatory autacoids (Fan et al, 1995; Griffioen and Molema, 2000). We have recently reported that the prostaglandins, which are proinflammatory autacoids and can induce several growth factors and the proliferation of endothelial cells in vitro and in vivo (Form and Auerbach, 1983; Ziche et al, 1982), have a crucial role in the enhancement of neovascularization (Majima et al, 2000). This action of prostaglandins was mainly mediated by the induction of vascular endothelial growth factor (VEGF) (Majima et al, 2000).

\section{DOI: 10.1097/01.LAB.0000018885.36823.D6}

Received January 25, 2002.

This work was supported by a grant from Academic Frontier Project of The Ministry of Education, Science, Sports, and Culture, and a grant from The Ministry of Education, Science, Sports, and Culture (No. 12470529).

Address reprint requests to: Dr. Masataka Majima, Department of Pharmacology, Kitasato University School of Medicine, Kitasato 1-15-1, Sagamihara, Kanagawa 228-8555, Japan.E-mail:en3m-mjm@asahi-net.or.jp
Kinin is a multifunctional peptide, which can induce inflammation, increase in sodium excretion from kidney, and prostaglandin release (Bhoola et al, 1992; Katori and Majima, 1998; Majima and Katori, 1995). Activation of the intrinsic coagulation system resulted in the generation of kinins from the high molecular weight kininogen $(\mathrm{HK})$. Although kinins were reported previously to enhance angiogenesis (Ferreira et al, 1992; Hu and Fan, 1993; Morbidelli et al, 1998) and proliferation of vascular endothelial cells (Morbidelli et al, 1998), the controversial results that the domain 5 of $\mathrm{HK}$, one of the component of kallikrein-kinin system (KKS), inhibited angiogenesis in vivo was recently reported (Colman et al, 2000). They reported that the activated $\mathrm{HK}$, which had already released kinins, was equally potent to the domain 5 of $\mathrm{HK}$ in terms of inhibition of angiogenesis. By contrast, it was postulated that the endogenous kinins, such as bradykinin (BK) and kallidin, contributed to the growth of tumors by increasing vascular permeability, which can supply nutrients, including growth factors from the circulation (Wu et al, 1998). There has not been conclusive evidence which of these accumulated results is predominant in the development of angiogenesis. Further, the precise mechanism of kinin generation in relation to angiogenesis and the involvement of the compartments of KKS in the enhancement of the angiogenesis and tumor growth have not been fully investigated. 
Recent studies have confirmed the hypothesis that tumor growth in general is dependent on angiogenesis (Folkman, 1996), and the triggers for the processes in angiogenesis are activated in the early stage of tumor development (Hanahan and Folkman, 1996). It was recently emphasized that angiogenesis among tumorsurrounding stromal cells is crucial for the growth of tumors (Fukumura et al, 1997). Thus, the control of tumor-dependent angiogenesis in the stroma is expected to be a useful novel approach to prevention or therapy of cancers.

In this study, we used the quantitative in vivo angiogenesis models designed to mimic tumor stromal response (Majima et al, 2000; Muramatsu et al, 2000a, 2000b). We first tested whether the endogenous kinins generated from KKSs take part in the augmentation of angiogenesis using a mutant rat that lacks the precursor proteins of kinins, HK, and low molecular weight kininogen (LK) (Hayashi et al, 1993). Because this rat lacks HK, we can eliminate the involvement of activated HK that was reported to be anti-angiogenic. Second, we further investigated the involvement of KKSs in tumor-associated angiogenesis using tumor cell-containing Millipore chambers.

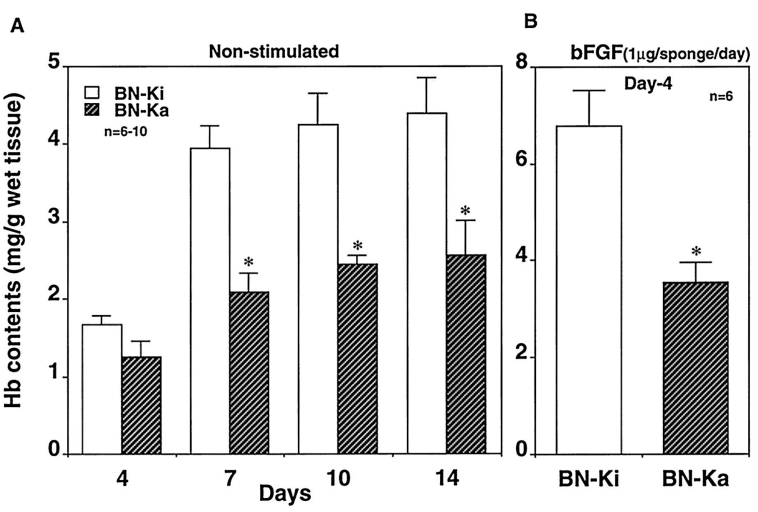

Figure 1.

Angiogenesis in rat sponge granulomas. Four, 7, 10, and 14 days after implantation, the sponges with the surrounding granulation tissue were excised to measure the hemoglobin content as an index of angiogenesis. A, Angiogenesis in the sponge granuloma without topical injections of growth factors. B, Angiogenesis after daily topical injections of basic fibroblast growth factor (bFGF) at $1 \mu \mathrm{g} / \mathrm{sponge/day,} \mathrm{once} \mathrm{a} \mathrm{day.} \mathrm{Each} \mathrm{column} \mathrm{represents} \mathrm{the}$ mean \pm SEM of 6 to 10 sponges (A) and 6 sponges (B). BN-Ki, Brown Norway Kitasato rats; $B N-K a$, Brown Norway Katholiek rats. ${ }^{*} p<0.05$ (comparing sponges from BN-Ki with those from BN-Ka on the same experimental day. A, ANOVA; $B, t$ test).

\section{Results \\ Time Course of Angiogenesis in Sponge Granulation Tissues in Brown Norway Katholiek Rats (BN-Ka ) and Brown Norway Kitasato Rats (BN-Ki)}

This sponge implantation model has a characteristic of chronic and proliferative inflammation, and is designed to quantify the proangiogenic response by determining the hemoglobin concentrations in the granulation tissues formed around the sponge implants. When circular sponge discs were implanted into the subcutaneous tissues in normal $\mathrm{BN}-\mathrm{Ki}$, the weights of the sponge granulation tissues increased gradually, and angiogenesis occurred gradually in this sponge granuloma (Fig. 1A). The development of angiogenesis observed in kininogen-deficient $\mathrm{BN}-\mathrm{Ka}$ was significantly suppressed, compared with that in normal rats (Fig. 1A). The direct topical injections of basic fibroblast growth factor (bFGF) significantly facilitated angiogenesis in both rats, but the difference between deficient $\mathrm{BN}-\mathrm{Ka}$ and normal $\mathrm{BN}-\mathrm{Ki}$ was also statistically significant (Fig. 1B). These results suggested that endogenous kinins exhibited a proangiogenic activity in this model.

\section{Effects of BK Receptor Antagonists on Angiogenesis in Sponge Granulation Tissues}

To identify the receptors of kinins involved, the effects of $\mathrm{BK}$ receptor antagonists $\left(\mathrm{B}_{1}\right.$ or $\left.\mathrm{B}_{2}\right)$ on angiogenesis were tested in this sponge model (Fig. 2). The natural development of angiogenesis without stimulation of the growth factor was suppressed with the daily topical injections of a $B_{1}$ receptor antagonist, desArg ${ }^{10}$-[Hoe140], and was also inhibited by those of the $B_{2}$ receptor antagonist, Hoe140. The inhibitory effects of a $B_{2}$ receptor antagonist on angiogenesis

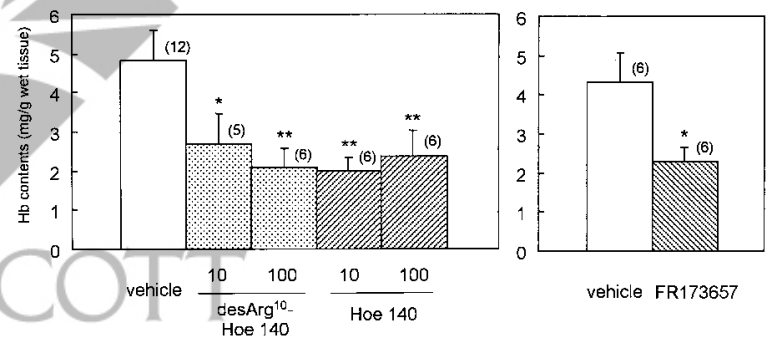

Figure 2.

Effect of bradykinin (BK) receptor antagonists on angiogenesis in sponge granulomas in normal rats. Seven days after implantation, the sponges with the surrounding granulation tissue were excised to measure the hemoglobin content as an index of angiogenesis. BK $\mathrm{B}_{1}\left(\right.$ desArg ${ }^{10}$-Hoe 140) and $\mathrm{B}_{2}$ (Hoe 140) receptor antagonists were topically injected into the sponge at 10 nmole/sponge (10) or $100 \mathrm{nmole} / \mathrm{sponge}$ (100) twice a day for 7 days. Another $B_{2}$ receptor antagonist, FR173657, was administered orally three times a day at a dose of $30 \mathrm{mg} / \mathrm{kg}$. Vehicle: topical administration of vehicle solution. Each column represents the mean \pm SEM of the number of sponges (n). ${ }^{*} p<0.05$; ${ }^{* *} p<0.01$ (compared with vehicle-treated sponges, ANOVA).

was also observed with another $B_{2}$ receptor antagonist, FR 173657 , which was an orally active antagonist (Fig. 2). These results suggested that both of $B_{1}$ and $B_{2}$ receptor signalings were responsible for the enhancement of angiogenesis in this model.

\section{Detection of Tissue Kallikrein-Like Activity in Sponge Granuloma and Effects of Topical Injections of Aprotinin or Soy Bean Trypsin Inhibitor (SBTI) on Angiogenesis}

To characterize the kallikrein activity to generate endogenous kinins, we determined the amidase activity, which was estimated by the degradation rate of the synthetic substrate for kallikrein (Pro-Phe-Arg-MCA). The amidase activity detected in the granulation tissues at the levels of $17.6 \pm 2.010^{-12}$ mole/10 minutes/mg protein $(n=4)$ (Fig. 3A). This activity was 
A

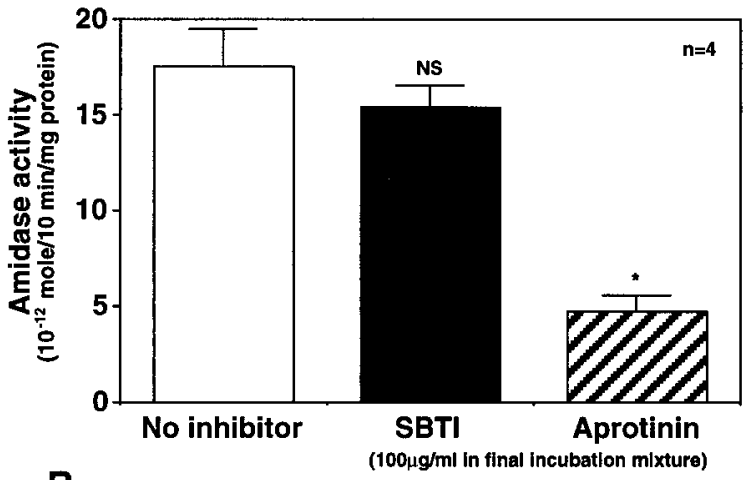

B

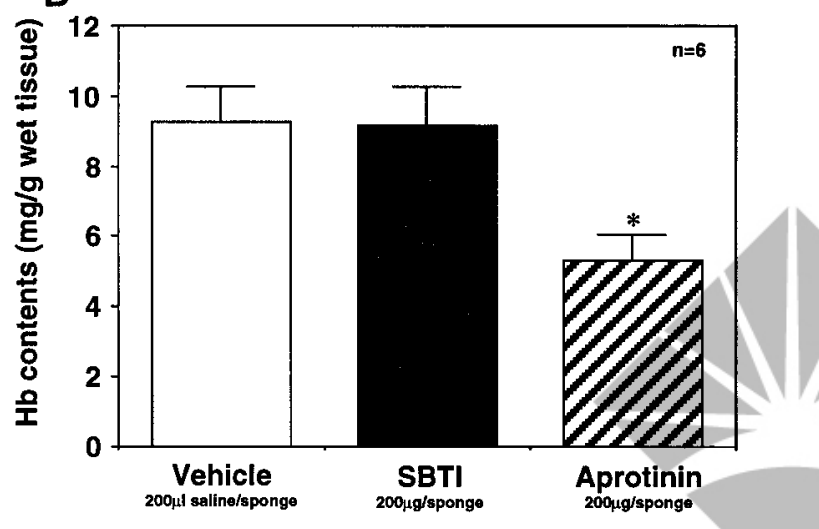

Figure 3.

Effect of kallikrein inhibitors on amidase activity and angiogenesis in sponge granulomas in normal rats. A, 7 days after implantation, the sponges with the surrounding granulation tissue were excised and homogenized. The kallikrein activity was determined in the supernatants of homogenates in the presence of $100 \mu \mathrm{g} / \mathrm{ml}$ of soy bean trypsin inhibitor (SBTI) or of aprotinin, or in the absence (No inhibitor) of kallikrein inhibitors. B, SBTI and aprotinin were topically injected into the sponge at $100 \mathrm{\mu g} / \mathrm{sp}$ onge (twice a day) for 7 days. To vehicle-treated rats, vehicle solution (physiological saline, $100 \mu \mathrm{l} / \mathrm{sponge/}$ day) was administered topically once a day. The sponge implants were topically stimulated with $100 \mathrm{ng} / \mathrm{site} / \mathrm{day}$ of bFGF. Each column represents the mean \pm SEM of the number of sponges $(n)$. N.S., not significant. * $p<0.05$ (versus no inhibitor present or with vehicle-treated sponges, ANOVA).

not suppressed by the addition of SBTI to the incubation mixture, but was suppressed significantly $(p<$ 0.05) with that of aprotinin (Fig. 3A).

The effects of kallikrein inhibitors topically administered to the sponges on angiogenesis are summarized in Figure 3B. Although the topical injection of SBTI, an inhibitor of plasma kallikrein, did not reduce the bFGFstimulated angiogenesis at all, those of an inhibitor, aprotinin, which can inhibit both plasma kallikrein and tissue kallikrein reduced it significantly (Fig. 3B). These results suggested that tissue kallikrein had a significant role in enhancement of angiogenesis in this model.

\section{Effects of Topical Injections of $L K$}

Figure 4A depicts the angiogenesis in the granulation tissues formed around the sponges implanted in BN$\mathrm{Ka}$, which received daily topical injection of the natural preferential substrate for tissue kallikrein, LK. Topical applications of LK for 7 days markedly enhanced
A

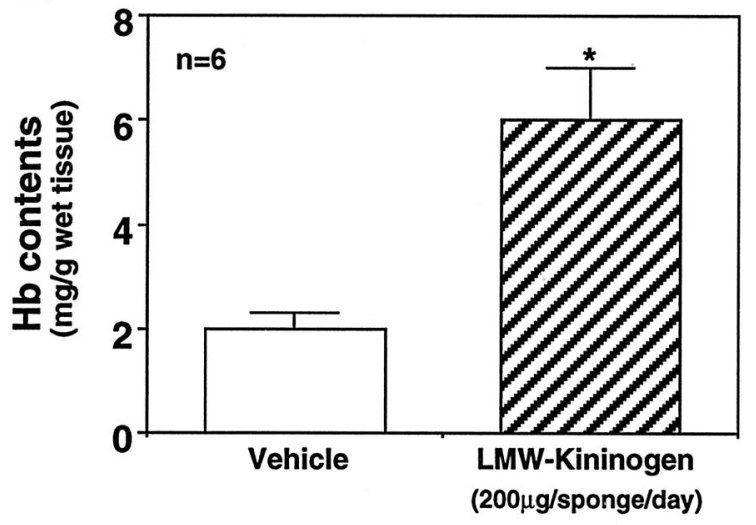

B

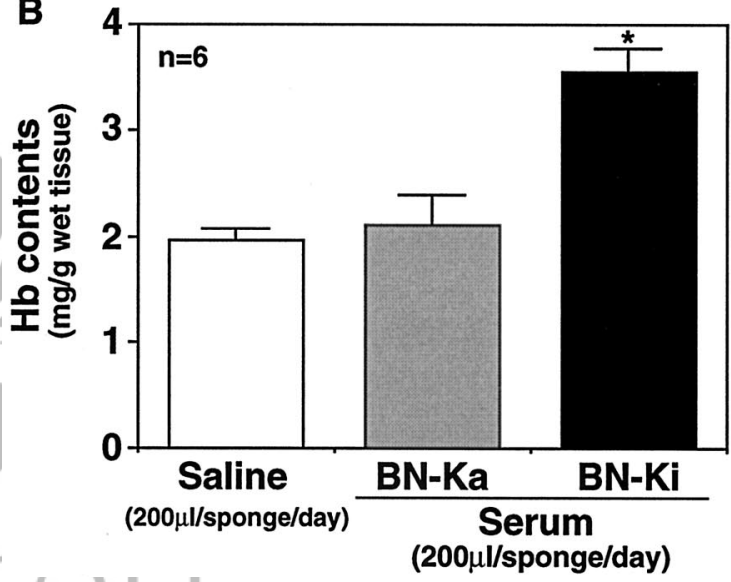

Figure 4.

Effect of topical injections of low molecular weight kininogen $(L K)$ or serum from rats on angiogenesis in sponge granulomas in rats. A. The purified LK (LMW-kininogen) was topically injected into the sponge at $100 \mu \mathrm{g} / \mathrm{sponge}$ (twice a day) for 7 days. B, Serum prepared from kininogen-deficient BN-Ka rats or from normal BN-Ki rats was topically injected into the sponges implanted in BN-Ka twice a day (100 $\mu$ l/sponge) for 7 days. To vehicle-treated rats, physiological saline (100 $\mu$ //sponge) was administered topically twice a day. Each column represents the mean \pm SEM of number of sponges (n). * $p$ $<0.05$ (versus vehicle-treated sponges using (A) $t$ test or (B) ANOVA.

angiogenesis, compared with vehicle injections (Fig. 4A). This result suggested that kinins generated from LK through the action of tissue kallikrein enhanced angiogenesis in this model.

\section{Effects of Topical Injections of Serum from BN-Ka or $B N-K i$ on Angiogenesis in the Sponge Granulation Tissues in BN-Ka}

Plasma exudation may enhance the angiogenesis by increasing the supply of plasma containing the growth factors and the oxygen. To mimic increased plasma extravasation, we topically injected serum from the rats used in this study.

During the preparation of serum, a precursor protein for kinin, HK, was completely converted to activated HK through the activation of factor XII, and further, the kinin generated from it was also completely degraded by the kininases contained in the blood samples. Thus, the serum from BN-Ki contained activated HK 
and LK, whereas that from BN-Ka lacked both activated HK and LK.

Daily topical injections of serum (100 $\mu \mathrm{l} / \mathrm{sponge/}$ day, twice a day) from $\mathrm{BN}-\mathrm{Ka}$ for 7 days to the sponges implanted in $\mathrm{BN}-\mathrm{Ka}$ did not increase the angiogenesis in comparison with that observed in the rats receiving the same volume of physiological saline (Fig. 4B). By contrast, topical injections of the same volume of serum from BN-Ki significantly increased the angiogenesis in $\mathrm{BN}-\mathrm{Ka}$ (Fig. 4B). These results suggested that enhancement of angiogenesis in this model depended not simply on the increased supply of serum, but also on the supply of LK, a preferential substrate for tissue kallikrein.

\section{Effects of Topical Applications of BK and a Nonpeptide Mimic of BK on Angiogenesis in the Sponge Granulation Tissues}

Angiogenesis in the sponge granulation tissues without stimulation with bFGF was significantly enhanced by topical applications of a nonpeptide mimic of BK, FR190997, when estimated 7 days after the implantation (Fig. 5). By contrast, the daily topical injections of BK (20 or $50 \mathrm{nmole/sponge/day)} \mathrm{did} \mathrm{not} \mathrm{significantly}$ enhance the development of angiogenesis in this model (Fig. 5). The $\mathrm{B}_{1}$ receptor agonist desArg ${ }^{10}$ kallidin (50 nmole/sponge/day) also did not increase angiogenesis (data not shown). These results suggested that the sponge granulation tissues contained the kinin-degrading enzyme, and that B2 receptor signaling certainly exhibited a proangiogenic activity.

\section{Expression of VEGF in Sponge Granulation Tissues}

Our previous observations suggested that VEGF, a potent proangiogenic factor, contributes to the angiogenic response in this sponge model (Majima et al, 2000). Topical application of a nonpeptide mimic of BK, FR190997, which enhanced angiogenesis (Fig. 5),
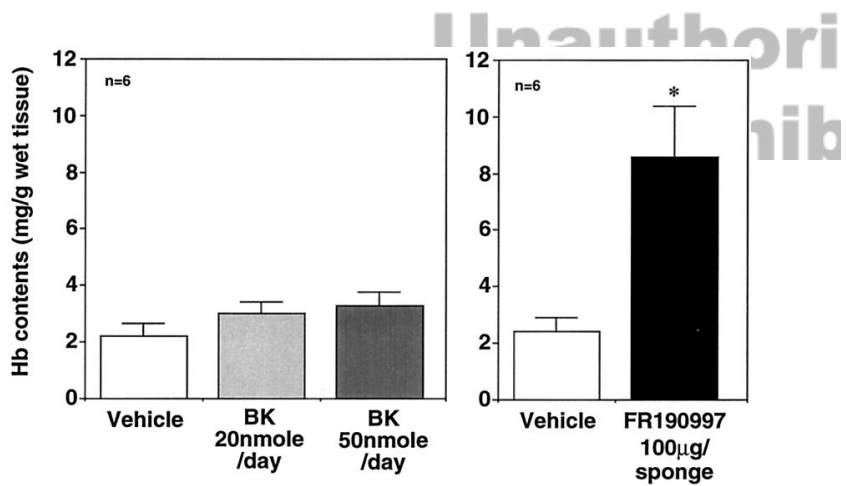

Figure 5.

Effect of topical applications of BK and nonpeptide mimic of BK, FR1990997 on angiogenesis in sponge granulomas in normal rats. Bradykinin (BK) was topically injected into the sponges at 20 or 50 nmole/sponge (once a day) for 7 days. FR190997 (100 $\mu \mathrm{g} / \mathrm{sponge}$ ) was topically placed into the sponge, which was then implanted. To vehicle-treated rats, vehicle solution (physiological saline, $100 \mu \mathrm{l} / \mathrm{sponge/day)} \mathrm{was} \mathrm{administered} \mathrm{topically} \mathrm{twice} \mathrm{a} \mathrm{day,} \mathrm{or}$ DMSO (vehicle) was topically placed into the sponge. Each column represents the mean \pm SEM of the number of sponges $(n) .{ }^{*} p<0.05$, versus vehicle-treated sponges (ANOVA, $t$ test). markedly increased the expressed levels of mRNA of VEGF in the granulation tissues (Fig. 6A). To know the capacity of endogenous kinin to induce VEGF, we next examined the expression of VEGF in the granulation tissues from $\mathrm{BN}-\mathrm{Ki}$ and $\mathrm{BN}-\mathrm{Ka} 7$ days after sponge implantation without stimulation. The expressed levels of VEGF mRNA were apparently enhanced in BN-Ki, compared with BN-Ka (Fig. 6B). These results showed that the endogenous kinins up-regulated VEGF expression in this model.

\section{Tumor-Associated Angiogenesis in BN-Ka and BN-Ki}

Finally, we examined the role of endogenous kinin in tumor-associated angiogenesis using the mutant rats. Angiogenesis observed around the Millipore chamber containing the fixed number of Walker 256 cells was markedly suppressed in $\mathrm{BN}-\mathrm{Ka}$, compared with $\mathrm{BN}-\mathrm{Ki}$ (Fig. 7). The hemoglobin content of the granulation tissues that developed around the chamber implanted in $\mathrm{BN}-\mathrm{Ka}$ was significantly lower than that in $\mathrm{BN}-\mathrm{Ka}$ (Fig. 7).

\section{Discussion}

Kinins are potent vasoactive peptides that are released from their precursor proteins, kininogens, by kallikrein. $\mathrm{BN}-\mathrm{Ka}$ is an experimental animal, which lacks the capacity for kinin generation. Very low plasma levels of HK and LK were attributable to the

\section{A}

FR190997

VEGF

\section{GAPDH}
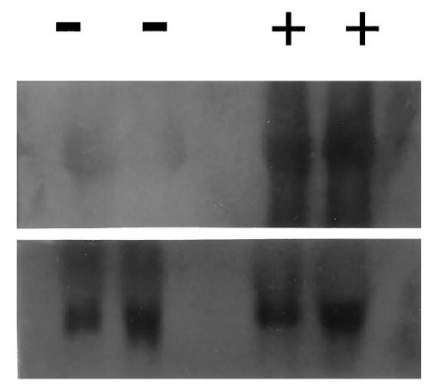

B

\section{VEGF}

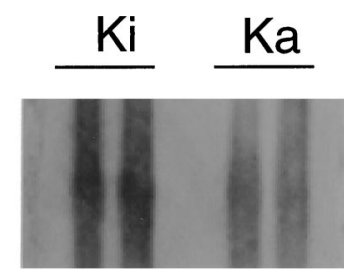

\section{GAPDH}

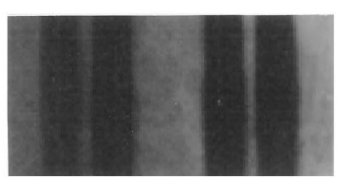

Figure 6.

Expression of VEGF in granulomas. A, Expression of VEGF 7 days after the topical application of a nonpeptide mimic of BK, FR1990997. The experiments were performed as in Figure 5. B, VEGF expression 7 days after implantation in BN-Ki $(K I)$ rats or BN-Ka (Ka) rats. mRNA levels were assessed by Northern blotting. 


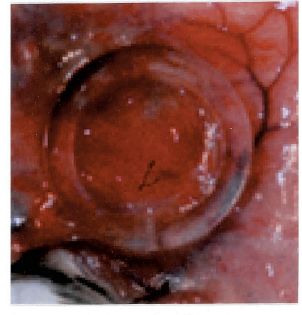

BN-Ki

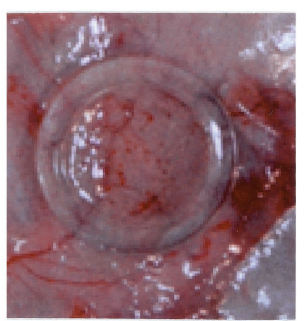

$\mathrm{BN}-\mathrm{Ka}$

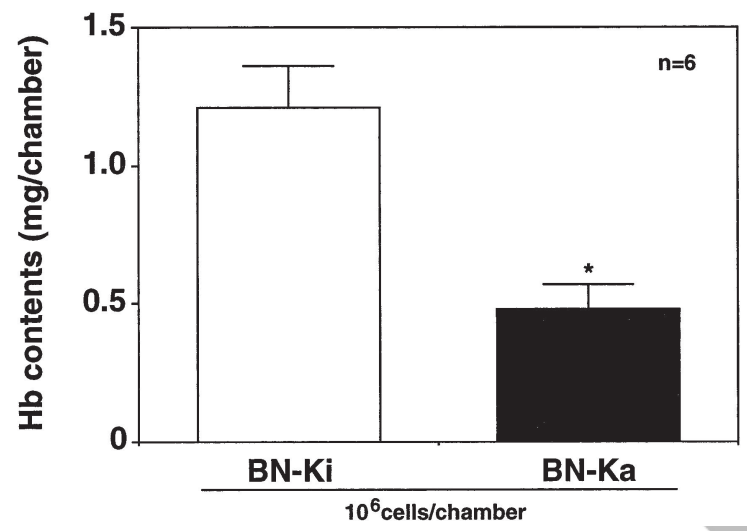

Figure 7.

Tumor-associated angiogenesis on the implanted chambers containing Walker 256 cell suspensions in kininogen-deficient BN-Ka rats or in normal BN-Ki rats. A 0.2-ml Millipore chamber (filter pore size, $0.45 \mu \mathrm{m}$ ) was filled with Walker 256 cell suspension, and was implanted subcutaneously into the dorsum of the rats. Four days after the implantation, the granulation tissues formed on the Millipore chamber were removed, and the hemoglobin concentrations in the granulation tissues were determined as an index of tumor-associated angiogenesis. Each value represents the mean \pm SEM. $n=6$ chambers examined. ${ }^{*} p<0.05$ ( $t$ test).

inability to secrete these kininogen moieties from the liver of this strain, because of one-point mutation of alanine163 to threonine in the kininogen moiety, although the hepatic cells of the mutant BN-Ka produced kininogens with one-point mutation, which were very similar in molecular weight to the kininogens produced BN-Ki (Hayashi et al, 1993). Comparison of $\mathrm{BN}-\mathrm{Ka}$ with normal $\mathrm{BN}-\mathrm{Ki}$ allowed us to study the pathophysiologic roles of endogenous kinins in many situations (Majima and Katori, 1995).

Kinins were reported previously to enhance angiogenesis in vivo and in vitro, when administered in their pharmacologic doses (Ferreira et al, 1992; $\mathrm{Hu}$ and Fan, 1993; Morbidelli et al, 1998). In the same sponge models as we used in the present study, BK topically injected into the sponges together with IL-1 was reported to increase angiogenesis mainly through the action of a $B_{1}$ receptor (Hu and Fan, 1993). This was also confirmed in vitro, when assessed from the vascular endothelial cell proliferation (Morbidelli et al, 1998). However, the crucial roles of endogenous kinin generated through the action of kallikrein from a natural substrate kininogen in angiogenesis have not been fully investigated. The present study demon- strated that the endogenous kinins have a definitive facilitating action on the angiogenesis in the sponge implantation model (Fig. 1). The kinin involved in this angiogenesis may be generated from LK through the action of tissue kallikrein, because the protease inhibitor, SBTI, which can inhibit plasma kallikrein but not tissue kallikrein, did not inhibit the angiogenesis; whereas aprotinin, a protease inhibitor that inhibits both plasma kallikrein and tissue kallikrein, did inhibit angiogenesis in this model (Fig. 3B). The fact that amidase activity, when assessed by the hydrolysis rate of the synthetic substrate for kallikrein, was strongly inhibited by aprotinin, but not by SBTI (Fig. $3 \mathrm{~A})$, further supported the suggestion that the tissue kallikrein-LK system is involved in the augmentation of this angiogenesis.

It was recently reported that recombinant domain 5 of $\mathrm{HK}$, one of the component of KKS, inhibited migration and proliferation of endothelial cells in vitro and angiogenesis in vivo (Colman et al, 2000). Further, they reported that the activated HK, which had already released kinins, but not intact HK, inhibited FGFstimulated angiogenesis as recombinant domain 5 of $\mathrm{HK}$ did. The levels of circulating and inactive HK appeared to be sufficient to show the anti-angiogenic activity, if HK was fully converted to its active form. But we cannot detect the full activation of HK in the circulation of normal rats implanted with the sponge (data not shown). In the present study, the angiogenesis was certainly suppressed in BN-Ka rats (Fig. 1), which lack activated HK together with LK. These results exclude the possibility that the active form of HK inhibits angiogenesis in this model.

The presence of tissue kallikrein in the blood vessels has been reported by many investigators (Madeddu et al, 1994; Nolly and Nolly, 1998; Nolly et al, 1994; Oza and Goud, 1992; Saed et al, 1990). The endogenous kinin may be generated by the tissue kallikrein-type proteases located in the vessels in the granulation tissues. The neovascularized vessels were generally immature, and these vessels lack smooth muscle layers in the initial phase of angiogenesis. But kallikrein-like activity was also reported to be present in the endothelial cells, which are major components of newly formed vessels.

LK, a substrate for tissue kallikrein, may be supplied from the circulation, judging from the more pronounced angiogenesis seen in $\mathrm{BN}-\mathrm{Ki}$ than in $\mathrm{BN}-\mathrm{Ka}$ (Fig. 1). The results of supplementation of purified LK (Fig. 4A) or serum from BN-Ki, but not BN-Ka (Fig. 4B), to the sponges also supported the view that the supply of LK from the circulation is the source of kinins. Although the presence of kininogens, including LK in the vascular smooth muscle and myocardium (Okamoto et al, 1998; Yayama et al, 1998) was reported, the possibility that kininogens may be supplied from the sites where angiogenesis is observable is not high in the present experiment, because differences of angiogenesis development were observable between $\mathrm{BN}-\mathrm{Ka}$ and BN-Ki (Fig. 1).

It was postulated that kinins may contribute to the growth of tumors by increasing vascular permeability, 
which increases the supply of nutrients, including growth factors and oxygen, from the circulation (Wu et al, 1998). The plasma exudation in the sponge models, if observed, may also facilitate angiogenesis. To mimic increased extravasation of plasma proteins, we injected serum from BN-Ki that contained LK together with the activated $\mathrm{HK}$, but not inactive $\mathrm{HK}$, as well as active proteins such as growth factors that may enhance angiogenesis. Topical injections of serum from $\mathrm{BN}-\mathrm{Ki}$ increased the angiogenesis, whereas those of serum from BN-Ka did not do so. These results suggested that enhancement of angiogenesis in this case depended not simply on the increased supply of proangiogenic factors possibly contained in the serum of both rats at the same levels, but also on the generation of kinins resulted from the supply of LK, a preferential substrate for tissue kallikrein present in the granulation tissues. Further, these results also showed that the anti-angiogenic activity of the active HK (Colman et al, 2000) was negligible in the present experimental conditions.

VEGF, which is also known as vascular permeability factor, is a 38-to-46-kd heparin-binding homodimeric glycoprotein belonging to the PDGF family (Ferrara et al, 1992; Senger et al, 1990). It is one of the major proteins that are specific endothelial mitogens in vitro (Connolly et al, 1989), and is a well-characterized secreted inducer of angiogenesis in vivo (Banai et al, 1994). We previously reported (Majima et al, 2000) that VEGF was induced in the sponge implantation model, and had a proangiogenic activity. The actual contribution of VEGF to the enhancement of angiogenesis was confirmed by topical injections of anti-sense oligonucleotide (Majima et al, 2000) and neutralizing antibody (Amano et al, 2001) against VEGF. An immunohistochemical study using rat VEGF antibody revealed that VEGF-positive cells were the fibroblast-like cells around the neovascularized blood vessels in this model (Majima et al, 2000). VEGF was more markedly expressed in the sponge granulation tissues in $\mathrm{BN}-\mathrm{Ki}$ than in BN-Ka (Fig. 6B), suggesting that the endogenous kinin induces VEGF and enhanced angiogenesis through this induction in this model. $B_{1}$ receptorsbut not $B_{2}$ receptors-were reportedly involved in the enhancement of angiogenesis in this sponge model under IL-1 stimulation (Hu and Fan, 1993). Upregulation of $B_{1}$ receptors by IL- 1 may be necessary to show the proangiogenic activity for BK or a selective $\mathrm{B}_{1}$ receptor agonist. In the present study, the topical injections of BK alone did not induce any angiogenic activity, but a nonpeptide mimic of BK, FR190997, which is resistant to BK-degrading proteases and selective for $B_{2}$ receptors, did induce such activity through the $B_{2}$ receptors (Fig. 5). Judging from the results using $B_{1}$ and $B_{2}$ receptor antagonists (Fig. 2), both $B_{1}$ and $B_{2}$ receptor signaling may actually enhance angiogenesis. The previous report, which concluded that $B_{2}$ receptors were not involved in the enhancement of angiogenesis, was made on the basis of the first-generation $B_{2}$ receptor antagonist, a peptide analog of $\mathrm{BK}$, that was not resistant to $\mathrm{BK}$ degrading enzymes, and had a partial agonistic action on $\mathrm{B}_{2}$ receptors ( $\mathrm{Hu}$ and Fan, 1993; Schachter et al, 1987). As shown in this experiment, not only the more stable $B_{2}$ receptor antagonist, Hoe140, but also the nonpeptide orally active $\mathrm{B}_{2}$ receptor antagonist, FR173657, significantly reduced angiogenesis (Fig. 2). These results taken together suggested that endogenous BK generated in the sponge granulation tissues facilitated the angiogenesis via $B_{1}$ and $B_{2}$ receptor signaling, both of which link to the same second messengers (Naraba et al, 1999). Although it is widely accepted that $B_{1}$ and $B_{2}$ receptors are located on the endothelial cells, it is plausible that the fibroblast-like cells, which expressed VEGF, may be the target cells for the endogenous kinins.

An important factor in the promotion of tumor growth is believed to be angiogenesis (Folkman, 1996). Substantial increases in tumor mass must be preceded by an increase in blood supply to provide the nutrients and oxygen required for tumor growth. It has been suggested that the mechanisms for promotion of angiogenesis are activated in the early stages of tumor development (Hanahan and Folkman, 1996). We have now shown with our Millipore chamber experiment that endogenous kinin certainly enhances tumor-associated angiogenesis (Fig. 7). BK was reported to induce the proliferation of cells, including endothelial cells, which play a major role in angiogenesis (el-Dahr et al, 1996; Goldstein and Wall, 1984; Kimball and Fisher, 1988; Marceau and Tremblay, 1986; Morbidelli et al, 1998), but some reports presented controversial results (Dixon and Dennis, 1997; Patel and Schrey, 1992; Yau et al, 1996). The effects of $\mathrm{BK}$ on cell proliferation in vitro were closely dependent on the kind of cells used as a target, and the culture conditions of the cells. The tumor cells themselves produced the inducers of angiogenesis, such as growth factors and prostanoids (Tujii et al, 1998), and this was confirmed in the present experiments, because the chamber containing only some vehicle solution medium (PBS) of the tumor cell suspension did not induce marked angiogenesis within 4 days of experimental periods, but markedly enhanced angiogenesis was observed in the granulation tissues formed around the chambers containing tumor cells. This result indicates that the tumor cells in the chamber secreted some angiogenic factors, but the amounts of these secretions did not differ between $\mathrm{BN}-\mathrm{Ki}$ and $\mathrm{BN}-\mathrm{Ka}$, because the implanted chambers contained the same number of tumor cells. It is plausible that tumor cells secreted kallikrein-like proteases that can convert kininogens to kinins, and that the kinins generated may act on the stromal cells to induce the angiogenic factor VEGF. In fact, it was reported that some tumor cells contained tissue kallikrein (Bhoola et al, 1992). The host microenvironment is thought to influence tumor progression (Fukumura et al, 1997; Gohongi et al, 1999; Williams et al, 2000). Recent results regarding stromal prostaglandins and VEGF expression revealed the significant roles of stromal cells in tumor-related angiogenesis and tumor growth (Williams et al, 2000). Kinins generated in the stroma may also induce VEGF, as in the case of 
sponge granulation tissues, and may enhance tumorassociated angiogenesis and tumor growth. Pharmacologic intervention in kinin generation or kinin receptor signaling during the development of tumorassociated angiogenesis may become a useful technique for the treatment of tumors, as well as of chronic proliferative inflammation.

In conclusion, the present results suggested that endogenous BK generated from tissue the kallikreinkinin system enhances angiogenesis in chronic and proliferative granuloma and stromal cells around the tumor, and that agents that act on the kallikrein-kinin system may become pharmacologic tools for controlling angiogenesis.

\section{Materials and Methods}

\section{The Rat Sponge Model}

Under light ether anesthesia, circular sponge discs were implanted into the subcutaneous tissue of the backs of male kininogen-deficient BN-Ka rats, which are incapable of kinin generation, and normal BN-Ki rats (male, 8-weeks-old) (Hayashi et al, 1993; Majima and Katori, 1995). The numbers of animals used are stated in each section of the description of the experiment. All rats were kept in a room with constant temperature $\left(25 \pm 1^{\circ} \mathrm{C}\right)$ and humidity $(60 \pm 5 \%)$ throughout the experimental periods, and were allowed free access to normal chow and water. The study was performed in accordance with the Guidelines for Animal Experiments of Kitasato University School of Medicine.

Neovascularization was assessed in terms of hemoglobin concentration in the granulation tissues formed around the sponge implants (Majima et al, 2000; Muramatsu et al, 2000a, 2000b). The detection limit of this assay was $0.1 \mathrm{mg} / \mathrm{g}$ wet tissue. The coefficient of variation, when determined in a sample with a hemoglobin concentration of $1 \mathrm{mg} / \mathrm{g}$ wet tissue, was $5 \%$ ( $n$ $=10$ ). We previously confirmed that the hemoglobin concentrations determined as above were well correlated with the density of newly-formed blood vessels in the granulation tissues, when assessed by immunohistochemical staining with von Willebrand factor (vWf) antibody (DAKO, Carpinteria, California) or HE staining (Muramatsu et al, 2000a).

To enhance the neovascularization of the sponge implants, basic fibroblast growth factor (bFGF; $1 \mu \mathrm{g} /$ sponge/day, human recombinant; Genzyme, Cambridge, Massachusetts) or its vehicle solution (physiological saline) were daily injected $(0.1 \mathrm{ml} / \mathrm{sponge}$, once a day) directly into the sponge implants using a $26 G$ needle under light ether anesthesia.

\section{Administration of BK, a Nonpeptide Mimic of BK, LK, or Serum from Brown Norway Rats}

A solution of BK (200 or $500 \mathrm{nmole} / \mathrm{ml}$ physiological saline, Peptide Institute, Osaka, Japan) or its vehicle solution (physiological saline) were injected once daily $(0.1 \mathrm{ml} / \mathrm{sponge})$ directly into the sponge implants. The circular discs of filter papers ( $3 \mathrm{~mm}$ in diameter), which absorbed $50 \mu \mathrm{l}$ of BK B2 receptor agonist solution (FR190997, at $2 \mathrm{mg} / \mathrm{ml}$ in 100\% DMSO, a gift from Fujisawa Pharmaceutical, Osaka, Japan) (Aramori et al, 1997a), were placed into the center of some of the sponges immediately before implantation. For the vehicle control rats, the filter papers which absorbed $50 \mu \mathrm{l}$ of the vehicle solution (absolute DMSO, Wako Pure Chemicals, Osaka, Japan), were put into the sponges. A solution $(1 \mathrm{mg} / \mathrm{ml}$, dissolved in physiological saline) of a preferential substrate for tissue kallikrein, LK (LMW kininogen, Seikagaku Kogyou, Tokyo), which was purified from bovine serum, was also topically injected $(0.1 \mathrm{ml} / \mathrm{sponge})$ into the sponges twice a day. From another set of nontreated BN-Ka and $\mathrm{BN}-\mathrm{Ki}$, the blood was collected under light ether anesthesia, and serum from each rat was obtained. The sera of five rats was pooled, and was topically ( 0.1 $\mathrm{ml} / \mathrm{sponge}$ ) injected into the sponges twice a day. Neovascularization was assessed by measuring the concentration of hemoglobin in the granulation as mentioned above.

\section{Administration of BK Receptor Antagonists or Kallikrein Inhibitors \\ A}

A BK $B_{2}$ receptor antagonist, FR173657: (E)-3(6acetamido-3-pyridyl)-N-[N-[2,4-dichloro-3-[(2-methyl-8quinolinyl) oxymethyl]phenyl]-N-methylaminocarbonylmethyl]acrylamide, kindly provided by Fujisawa Pharmaceutical (Aramori et al, 1997b; Asano et al, 1997) was orally administered (three times a day, $30 \mathrm{mg} / \mathrm{kg}$ ) to the rats receiving sponge implants from Day 0 throughout the experimental periods. Another $\mathrm{B}_{2}$ receptor antagonist, D-Arg[ $\left[\mathrm{Hyp}^{3}{ }^{3} \mathrm{Thi}^{5}, \mathrm{D}-\mathrm{Tic}^{7}, \mathrm{Oic}^{8}\right]$ BK (Hoe140) (Hock et al, 1991; Wirth et al, 1991a), purchased from the Peptide Institute, was topically administered (10 or 100 nmole/100 $\mu /$ physiological saline, twice a day) to the sponges throughout the experimental periods. $A B_{1}$ receptor antagonist, desArg ${ }^{10}$-D-Arg[Hyp ${ }^{3}$, Thi $^{5}$, D-Tic $^{7}$, $\left.\mathrm{Oic}^{8}\right]$ BK (desArg ${ }^{10}$-[Hoe140]) (Wirth et al, 1991b), which was obtained from Peninsula Laboratories (San Carlos, California), was also topically administered (10 or 100 nmole/100 $\mu$ l physiological saline, twice a day).

A protease inhibitor, SBTI (Worthington Biochem, Halls Mill Road, New Jersey), which can inhibit plasma kallikrein but not tissue kallikrein, was topically injected $(100 \mu \mathrm{g} / 100 \mu \mathrm{l}$ physiological saline, twice a day) for 4 days to the sponges receiving bFGF (100 $\mathrm{ng} /$ site/day). For vehicle-control rats, only physiological saline (100 $\mu$ l physiological saline, twice a day) was topically injected. Another protease inhibitor, aprotinin (Wako Pure Chemical Industries), which can inhibit both plasma kallikrein and tissue kallikrein, was topically administered (100 $\mu \mathrm{g}$ in $100 \mu \mathrm{l}$ physiological saline, twice a day) in exactly the same manner as SBTI. Neovascularization was assessed by measuring the concentration of hemoglobin in the granulation as mentioned above. 


\section{Measurement of Kallikrein Activity in Sponge Granulation Tissues}

Immediately after the exsanguination, the granulation tissue was extracted, and was washed with ice-cold physiological saline. After removal of the blood, the granulation tissue was homogenized on ice with Tris$\mathrm{HCl}$ buffers $(0.2 \mathrm{M}$, pH 8.5, containing $10 \mathrm{~mm}$ benzamidine, $4 \mathrm{ml} / \mathrm{g}$ wet granulation tissue). The supernatant after the centrifugation $\left(1,500 \times g, 4^{\circ} \mathrm{C}, 30\right.$ minutes) was used as a sample solution for kallikrein determination. The activity of the active kallikrein in the supernatant was measured using a peptidyl fluorogenic substrate selective for kallikrein, Pro-Phe-Argmethyl-coumarinylamide (Pro-Phe-Arg-MCA, Peptide Institute) (Jin et al, 1992). After 1 in 10 dilution of the original supernatant with $0.2 \mathrm{M}$ Tris- $\mathrm{HCl}$ buffer $(\mathrm{pH} 7.8)$, $10 \mu \mathrm{l}$ of the diluted supernatant was incubated for 30 minutes with $1 \mathrm{ml}$ of $5 \times 10^{-5} \mathrm{M}$ substrate solution in $0.05 \mathrm{M}$ Tris- $\mathrm{HCl}$ buffer containing $0.1 \mathrm{M} \mathrm{NaCl}$ and 0.01 M CaCl2 (pH8.0) for 30 minutes. Active kallikrein activity was characterized by the reduction of amidase activity in the presence of SBTI $(100 \mu \mathrm{g} / \mathrm{ml}$, at final concentration) and that in the presence of aprotinin (100 $\mu \mathrm{g} / \mathrm{ml}$, at final concentration).

\section{Northern Blot Analysis of VEGF}

Total RNA was isolated from RAW246.7 cells using ISOGEN. Approximately $1 \mu \mathrm{g}$ of total RNA was utilized as a template for reverse transcription in a reaction mixture of $\mathrm{p}(\mathrm{dN}) 6$ random primer and $\mathrm{AM} V$ reverse transcriptase (Roche Diagnostics GmbH, Basel, Switzerland). Fifty nanograms of cDNA was amplified by 2.5 units of Taq DNA polymerase in a $100 \mu$ l reaction containing $10 \mathrm{~mm}$ Tris- $\mathrm{HCl}$ (pH8.3), $50 \mathrm{~mm} \mathrm{KCl,} 1.5 \mathrm{~mm}$ $\mathrm{MgCl}_{2}, 0.2 \mathrm{~mm} \mathrm{dNTP}$, and two primers at $0.6 \mu \mathrm{m}$, 5'-aaccatgaactttctgctctc-3' (sense) and 5'gtgattttctggctttgttc-3' (antisense) for VEGF cDNA, or 5'-cccttcattgacctcaactacaatggt-3' (sense) and 5'gaggggccatccacagtcttctg-3' (antisense) for GAPDH. The reaction was allowed to proceed for 30 cycles, each cycle consisting of 45 seconds at $94^{\circ} \mathrm{C}, 60 \mathrm{~s}$ at $56^{\circ} \mathrm{C}$, and 60 seconds at $72^{\circ} \mathrm{C}$, and finally, a 10 minute extension at $72^{\circ} \mathrm{C}$. Amplified products in the reaction mixture were separated on a $2 \%$ agarose gel and extracted from the gel. Purified cDNA fragment was inserted into pGEM-T Easy vector (Promega, Madison, Wisconsin), and was transformed into E. coli JM109. Bacterial colonies were screened by EcoRI digestion of the plasmid, and DNA sequencing was performed to confirm the production of the desired clones for encoding VEGF or GAPDH cDNA. Total RNA for Northern blot was extracted from sponge granulation tissues as described above. Twenty micrograms of total RNA was separated by electrophoresis on $1 \%$ agarose gel containing $2.2 \mathrm{M}$ formaldehyde. After transfer, the RNA was covalently bound to Hybond-N+ (Amersham Pharmacia Biotech, Uppsala, Sweden) by alkaline-fixing and UV-crosslinking. For the preparation of mouse VEGF and GAPDH probes, cloned plasmid DNA containing p427 bp of
VEGF cDNA or 470 bp of GAPDH cDNA was digested with Ncol or Sall, respectively, to linearize, and each was used as a template to synthesize a digoxigeninUTP (Roche Diagnostics) labeled cRNA probe by in vitro transcription with SP6 or T7 RNA polymerase. The conditions of prehybridization and hybridization of membranes with the probe, as well as the subsequent procedures, were performed according to the manufacturer's instructions. Hybridized RNA with cRNA probe on a membrane was detected using alkaline phosphatase-labeled anti-digoxigenin antibody and its substrate, CDP-Star (Roche Diagnostics). X-ray film was exposed to the membrane to visualize the signal of chemiluminescence.

\section{Millipore Chamber Experiment}

Rat Walker 256 carcinoma cells (CCL-38) were cultured at $37^{\circ} \mathrm{C}$ in DMEM supplemented with $10 \%$ fetal bovine serum in a humidified atmosphere containing $5 \% \mathrm{CO}_{2}$. Walker 256 cells were washed with PBS and suspended in the same solution at a density of $1 \times 10^{8}$ cells $/ \mathrm{ml}$. A Millipore chamber (filter pore size, $0.45 \mu \mathrm{m}$; Millipore, Bedford, Massachusetts) was filled with 0.2 $\mathrm{ml}$ of either the cell suspension or PBS $(\mathrm{pH} 7.4,10 \mathrm{~mm}$, in physiological saline) and then implanted subcutaneously into the dorsal flank of rats (Iwamoto et al, 1996). Five days after implantation, the animals were killed and the granulation tissue that had formed around the chamber was immediately removed. The hemoglobin content of each of the excised tissues was then determined as a marker of tumor-associated angiogenesis by a method similar to those reported previously (Gatto et al, 1999; Kerr et al, 1999; Zeng et al, 2000).

\section{Statistical Analysis}

All values were expressed as the means \pm SEM. Statistical differences between the two groups were determined using Student's unpaired $t$ test, after confirming that the variance of data was not heterogeneous. For the results from multiple groups, factorial ANOVA was used to evaluate the significance of difference, followed by Scheffe's test. A $p$ value of less than 0.05 was considered to be significant.

\section{Acknowledgements}

The authors thank Ms. Michiko Ogino, Ms. Yukari Uemura, Ms. Keiko Nakamigawa, and Mr. Tomio Hagiwara for their skillful technical assistance. We also express thanks to Mr. C.W.P. Reynolds for correcting the English of this manuscript. FR190997 and FR173567 were kindly presented by Fujisawa Pharmaceutical Co. Ltd.

\section{References}

Amano H, Ando K, Minamida S, Hayashi I, Ogino M, Yamashina S, Yoshimura H, and Majima M (2001). Adenylate cyclase/protein kinase: A signaling pathway enhances angio- 
genesis through induction of vascular endothelial growth factor in vivo. Jpn J Pharmacol 87:181-188.

Aramori I, Zenkoh J, Morikawa N, Asano M, Hatori C, Sawai $\mathrm{H}$, Kayakiri $\mathrm{H}$, Satoh S, Inoue T, Abe $\mathrm{Y}$, Sawada $\mathrm{Y}$, Mizutani T, Inamura N, Nakahara K, Kojo H, Oku T, and Notsu $\mathrm{Y}$ (1997a). Nonpeptide mimic of bradykinin with long-acting properties at the bradykinin B2 receptor. Mol Pharmacol 52:16-20.

Aramori I, Zenkoh J, Morikawa N, O'Donnell N, Asano M, Nakamura K, Iwami M, Kojo H, and Notsu Y (1997b). Novel subtype-selective nonpeptide bradykinin receptor antagonists FR167344 and FR173657. Mol Pharmacol 51:171-176.

Asano M, Inamura N, Hatori C, Sawai H, Fujiwara T, Katayama A, Kayakiri H, Satoh S, Abe Y, Inoue T, Sawada Y, Nakahara K, Oku T, and Okuhara M (1997). The identification of an orally active, nonpeptide bradykinin B2 receptor antagonist, FR173657. Br J Pharmacol 120:617-624.

Banai S, Jaklitsch MT, Shou M, Lazarous DF, Scheinowitz M, Biro S, Epstein SE, and Unger EF (1994). Angiogeneticinduced enhancement of collateral blood flow to ischemic myocardium by vascular endothelial growth in dog. Circulation 89:2183-2189.

Bhoola KD, Figueroa CD, and Worthy K (1992). Bioregulation of kinins: Kallikreins, kininogens, and kininases. Pharmacol Rev 44:1-80.

Colman RW, Jameson BA, Lin Y, Johnson D, and Mousa SA (2000). Domain 5 of high molecular weight kininogen (kininostatin) down-regulates endothelial cell proliferation and migration and inhibits angiogenesis. Blood 95:543-550.

Connolly DT, Heuvelman DM, Nelson R, Olander JV, Eppley BL, Delfino JJ, Siegel NR, Leimgruber RM, and Feder J (1989). Tumor vascular permeability factor stimulates endothelial cell growth and angiogenesis. J Clin Invest 84:14701478.

Dixon BS and Dennis MJ (1997). Regulation of mitogenesis by kinins in arterial smooth muscle cells. Am J Physiol 273:C7-20.

el-Dahr SS, Dipp S, Yosipiv IV, and Baricos WH (1996). Bradykinin stimulates c-fos expression, AP-1-DNA binding activity and proliferation of rat glomerular mesangial cells. Kidney Int 50:1850-1855.

Fan TP, Jaggar R, and Bicknell R (1995). Controlling the vasculature: Angiogenesis, anti-angiogenesis and vascular targeting of gene therapy. Trends Pharmacol Sci 16:57-66.

Ferrara N, Houck K, Jakeman L, and Leung DW (1992). Molecular and biological properties of the vascular endothelial growth factor family of proteins. Endocr Rev 13:18-70.

Ferreira MA, Andrade SP, Pesquero JL, Feitosa MH, Oliveira GM, Rogana E, Nogueira JC, and Beraldo WT (1992). Kallikrein-kinin system in the angiogenesis. Agents Actions 38:165-174.

Folkman J (1971). Tumor angiogenesis: Therapeutic implications. N Engl J Med 285:1182-1186.

Folkman $\mathrm{J}$ (1996). What is the evidence that tumors are angiogenesis dependent? J Natl Cancer Inst 82:4-6.

Form DM and Auerbach R (1983). PGE2 and angiogenesis. Prog Soc Exp Biol Med 172:214-218.
Fukumura D, Yuan F, Monsky WL, Chen Y, and Jain RK (1997). Effect of host microenvironment on the microcirculation of human colon adenocarcinoma. Am J Pathol 151:679688.

Gatto C, Rieppi M, Borsotti P, Innocenti S, Ceruti R, Drudis T, Scanziani E, Casazza AM, Taraboletti G, and Giavazzi R (1999). BAY 12-9566, a novel inhibitor of matrix metalloproteinases with antiangiogenic activity. Clin Cancer Res 5:3603-3607.

Gohongi T, Fukumura D, Boucher Y, Yun CO, Soff GA, Compton C, Todoroki T, and Jain RK (1999). Tumor-host interactions in the gallbladder suppress distal angiogenesis and tumor growth: Involvement of transforming growth factor beta. Nature Med 5:1203-1208.

Goldstein RH and Wall M (1984). Activation of protein formation and cell division by bradykinin and des-Arg9-bradykinin. J Biol Chem 259:9263-9268.

Griffioen AW and Molema G (2000). Angiogenesis: Potentials for pharmacologic intervention in the treatment of cancer, cardiovascular diseases, and chronic inflammation. Pharmacol Rev 52:237-268.

Hanahan D and Folkman J (1996). Patterns and emerging mechanisms of angiogenic switch during tumorigenesis. Cell 86:353-364.

Hayashi I, Hoshiko S, Makabe O, and Oh-ishi S (1993). A point mutation of alanine 163 to threonine is responsible for the defective secretion of high molecular weight kininogen by the liver of brown Norway Katholiek rats. J Biol Chem 268:17219-17224.

Hock FJ, Wirth K, Albus U, Linz W, Gerhards HJ, Wiemer G, Henke S, Breipohl G, Konig W, and Knolle J (1991). Hoe 140 a new potent and long acting bradykinin-antagonist: In vitro studies. $\mathrm{Br} \mathrm{J}$ Pharmacol 102:769-773.

Hu DE and Fan TP (1993). [Leu ${ }^{8}$ des-Arg' ${ }^{9}$-bradykinin inhibits the angiogenic effect of bradykinin and interleukin-1 in rats. Br J Pharmacol 109:14-17.

Iwamoto M, Nakayama Y, Tanaka NG, Goryo M, and Okada K (1996). Quantification of tumor-induced angiogenesis by image analysis. Int J Exp Path 77:109-114.

Jin HY, Katori M, Majima M, and Sunahara N (1992). Increased secretion of glandular-kallikrein in the bronchial washings induced by intravenous injection of leukotriene C4 in guinea-pigs. Br J Pharmacol 105:632-638.

Katori M and Majima M (1998). Preventive role of renal kallikrein-kinin system in the early phase of hypertension and development of new antihypertensive drugs. Adv Pharmacol 44:147-224.

Kerr JS, Wexler RS, Mousa SA, Robinson CS, Wexler EJ, Mohamed S, Voss ME, Devenny JJ, Czerniak PM, Gudzelak A Jr, and Slee AM (1999). Novel small molecule alpha v integrin antagonists: Comparative anti-cancer efficacy with known angiogenesis inhibitors. Anticancer Res 19:959-968.

Kimball ES and Fisher MC (1988). Potentiation of IL-1induced BALB/3T3 fibroblast proliferation by neuropeptides. J Immunol 141:4203-4208.

Madeddu P, Varoni MV, Demontis MP, Fattaccio MC, Parpaglia PP, and Glorioso N (1994). A kallikrein-like enzyme in the aorta of normotensive and hypertensive rats. Hypertension 23:899-902 
Majima M, Hayashi I, Muramatsu M, Katada J, Yamashina S, and Katori M (2000). Cyclo-oxygenase-2 enhances basic fibroblast growth factor-induced angiogenesis through induction of vascular endothelial growth factor in rat sponge implants. Br J Pharmacol 130:641-649.

Majima M and Katori M (1995). Approaches to the development of novel antihypertensive drugs: Crucial role of the renal kallikrein-kinin system. Trends Pharmacol Sci 16:239-246.

Marceau F and Tremblay B (1986). Mitogenic effect of bradykinin and of des-Arg ${ }^{9}$-bradykinin on cultured fibroblasts. Life Sci 39:2351-2358.

Michaelson IC (1948). The mode of development the vascular system of the retina, with some observations on its significance for certain retinal diseases. Trans Ophthalmol UK 68:137-180.

Morbidelli L, Parenti A, Giovannelli L, Granger HJ, Ledda F, and Ziche M (1998). B1 receptor involvement in the effect of bradykinin on venular endothelial cell proliferation and potentiation of FGF-2 effects. Br J Pharmacol 124:1286-1292.

Muramatsu M, Katada J, Hattori M, Hayashi I, and Majima M (2000a). Chymase mediates mast cell-induced angiogenesis in hamster sponge granulomas. Eur J Pharmacol 402:181191.

Muramatsu M, Katada J, Hayashi I, and Majima M (2000b). Chymase as a proangiogenic factor: A possible involvement of chymase-angiotensin-dependent pathway in the hamster sponge angiogenesis model. J Biol Chem 275:5545-5552.

Naraba H, Ueno A, Yoshimura M, Kosugi Y, and Oh-ishi S (1999). Examination of signal transduction pathway of stimulated B1 and B2 kinin receptors: MAP kinase pathway to AP-1 translocation in HEK193 cells. Immunopharmacology 45:35-38.

Nolly H, Carretero OA, Lama MC, Miatello R, and Scicli AG (1994). Vascular kallikrein in dexycorticosterone acetatesalt hypertensive rats. Hypertension 23(Suppl 1):I185-1188.

Nolly H and Nolly A (1998). Release of endothelial-derived kallikrein, kininogen and kinins. Biol Res 31:169-174.

Okamoto H, Yayama K, Shibata H, Nagaoka M, and Takano M (1998). Kininogen expression by rat vascular smooth muscle cells: Stimulation by lipopolysaccharide and angiotensin II. Biochim Biophys Acta 1404:329-337.

Oza NB and Goud HD (1992). Kininogenase of the aortic wall in spontaneously hypertensive rats. J Cardiovasc Pharmacol 20:1-3.

Patel KV and Schrey MP (1992). Inhibition of DNA synthesis and growth in human breast stromal cells by bradykinin: Evidence for independent roles of B1 and B2 receptors in the respective control of cell growth and phospholipid hydrolysis. Cancer Res 52:334-340.
Peacock DJ, Banquerigo ML, and Brahn E (1992). Angiogenesis inhibition suppresses collagen arthritis. J Exp Med 175:1135-1138.

Saed GM, Carretero OA, MacDonald RJ, and Scicli AG (1990). Kallikrein messenger RNA in rat arteries and veins. Circ Res 67:510-516.

Schachter M, Uchida Y, Longridge DJ, Labedz T, Whalley ET, Vavrek RJ, and Stewart JM (1987). New synthetic antagonists of bradykinin. Br J Pharmacol 92:851-855.

Senger DR, Connoly DT, Water L, Feder J, and Dvorak HF (1990). Purification and NH2-terminal amino acid sequence of guinea pig tumor-secreted vascular permeability factor. Cancer Res 50:1774-1778.

Tujii M, Kawano S, Tsuji S, Sawaoka H, Hori H, and DuBois RN (1998). Cyclooxygenase regulates angiogenesis induced by colon cancer cells. Cell 93:705-716.

Williams CS, Tsujii M, Reese J, Dey SK, and DuBois RN (2000). Host cyclooxygenase-2 modulates carcinoma growth. J Clin Invest 105:1589-1594.

Wirth K, Breipohl G, Stechl J, Knolle J, Henke S, and Scholkens B (1991a). DesArg9-D-Arg[Hyp3,Thi5,DTic7,Oic8]bradykinin (desArg10-[Hoe140]) is a potent bradykinin B1 receptor antagonist. Eur J Pharmacol 205:217-218.

Wirth K, Hock FJ, Albus U, Linz W, Alpermann HG, Anagnostopoulos $\mathrm{H}$, Henk S, Breipohl G, Konig W, and Knolle J (1991b). Hoe 140 a new potent and long acting bradykininantagonist: In vivo studies. Br J Pharmacol 102:774-777.

Wise GN (1956). Retinal neovascularization. Trans Am Ophthalmol Soc 54:729-826.

Wu J, Akaike T, and Maeda H (1998). Modulation of enhanced vascular permeability in tumors by a bradykinin antagonist, a cyclooxygenase inhibitor, and a nitric oxide scavenger. Cancer Res 58:159-165.

Yau L, Pinsk M, and Zahradka P (1996). Inhibition of RNA synthesis by bradykinin involves both the $\mathrm{B} 1$ and $\mathrm{B} 2$ receptor subtypes. Arch Biochem Biophys 328:115-121.

Yayama K, Shibata H, Takano M, and Okamoto H (1998). Expression of low-molecular-weight kininogen in mouse vascular smooth muscle cells. Biol Pharm Bull 21:772-774.

Zeng G, Gao L, Birkle S, and Yu RK (2000). Suppression of ganglioside GD3 expression in a rat F-11 tumor cell line reduces tumor growth, angiogenesis, and vascular endothelial growth factor production. Cancer Res 60:6670-6676.

Ziche M, Jones J, and Gullino PM (1982). Role of prostaglandin $\mathrm{E} 1$ and copper in angiogenesis. J Natl Cancer Inst 69:475-482. 